\title{
Fotografías cusqueñas atravesando el indigenismo
}

\section{Cusco Photographs Going Through the Indigenist Movement}

\author{
Paula Trevisan \\ Universidad Nacional San Antonio Abad del Cusco. Perú \\ paulatrevisancusco@gmail.com
}

Luis Massa

Universiodad Nacional de Buenos Aires

paracas@ar.inter.net

Resumen • Viajeros foráneos exploran el Perú en la segunda mitad del siglo XIX registrando impresiones de lo indio. En Lima, en forma simultánea, fotógrafos peruanos y extranjeros consolidan un mercado de la imagen. A comienzos del siglo XX y durante cuatro décadas, en Cusco, el movimiento indigenista disputa por afianzarse. Este proceso de revalorización, donde lo étnico se reposiciona y jerarquiza, es materia interpeladora de las artes. Es así como las letras y otras expresiones estéticas se vieron implicadas por las ideas indigenistas, atravesándolas para surgir nutridas desde ese ideario. El pasaje a través de este espacio y su incidencia en el cuerpo de la imagen fotográfica, es el tema que intenta explorar este artículo, considerando distintos momentos de la fotografía andina y sus artífices.

Palabras clave: fotografía, Cusco, indigenismo, alteridad, idealización.

Abstract • Foreign travelers explore Peru during the second half of the XIX century, capturing impressions of the Indian culture; simultaneously in Lima, Peruvian photographers and those from abroad strengthen a market of images. At the beginning of the XX century and for four decades, the Indigenist movement struggled for consolidation. This revaluation process, where the ethnic repositions itself and its hierarchy, is a questioned matter in the Arts. As well as Liberal Arts, other aesthetical expressions were implicated by indigenous ideas, going through them so that they could emerge nourished from those principles. The passage throughout this space and its impact on the body of the photographic image, become the subject this work intends to explore, considering diverse moments of the Andean photography and its artificers.

Keywords: photography, Cusco, indigenism, alterity, idealization. 
La imagen visual sirve para confundir

lo verídico y lo verosímil porque la imagen gráfica no asevera, sino que impone, directa

y sencillamente, sobre el espectador.

Rolena Adorno ${ }^{1}$

\section{FORÁNEOS Y LOCALES EN LA CAPTURA DE LO INDIO²}

Efraim George Squier, diplomático norteamericano, llega a Lima en 1863. Su misión era de resolver el conflicto suscitado por la comercialización del guano entre Estados Unidos y Perú. Cumple exitosamente esta tarea y decide entonces emprender un viaje a través de los Andes. Amigo de Prescott ${ }^{3}$, había tenido experiencia en exploraciones arqueológicas en el Valle del Misisipi, tal cual lo refiere Porras Barrenechea en el prólogo que acompaña la edición en español de la obra de Squier titulada: Un viaje por tierras Incaicas. Crónicas de una expedición arqueológica (1863-1865). ${ }^{4}$ Ilustrada con más de doscientos grabados y múltiples planos de plantas arquitectónicas (lámina 1). Squier habría estudiado en su juventud ingeniería civil, lo que es notorio en la ductilidad con que realiza la reproducción de edificios, paisajes, puentes y caminos. Sobre la autoría de las fotos desde las cuales fueron recreadas muchas de sus ilustraciones, se sabe poco ${ }^{5}$. Es probable que a Squier lo haya acompañado, en parte de su periplo, el excéntrico fotógrafo Augustus Le Plongeon, quien posteriormente trabajara en Yucatán y a quien se le atribuye la denominación de Chac Mool dada al célebre altar de sacrificios tallado en piedra, utilizado en Mesoamérica precolombina. Le Plongeon experimentó en algunas oportunidades con imágenes estereoscópicas, que consistían en una serie de dos fotografías de la misma escena tomadas con una cámara provista de dos lentes separados, distantes uno del otro en relación a la distancia de los ojos humanos. Posteriormente las dos imágenes se montaban en paralelo para ser observadas con un visor binocular que generaba en el observador un efecto tridimensional de la escena (Massa, 2009: 349). Del corpus de fotos que sirven de modelo a las ilustraciones de Squier muy poco se sabe. Daniel Buck señala que "Squier se vio forzado a aprender fotografía, después que su fotógrafo, apodado «Mr. $\mathrm{P}$ » muriera en el trayecto de Perú a Bolivia» (1999: 122). Desconocemos el paradero de dichas imágenes.

En 1868 llegan a América dos jóvenes geólogos alemanes, Moritz Alphons Stübel y Wilheim Reiss. Ambos compartían el interés por la vulcanología, a tal punto que deciden iniciar una expedición a Hawai para realizar estudios en la materia. Probablemente inspirados en los trabajos del notable geógrafo y explorador prusiano Alexander von

En Imágenes de la resistencia indígena y esclava. Roger Zapata editor, «Retórica y resistencias pictóricas. El grabado y la polémica en los escritos sobre el Perú en los siglos XVI y XVII». Lima 1990.

Este artículo ha contado con la inestimable colaboración de Renata Massa.

3 William H. Prescott, historiador estadounidense quien publicara en Boston (1847) su famosa obra Historia de la conquista del Perú.

4 Editada por Editorial Amigos del Libro, Bolivia 1974, publicada originalmente bajo el título Perú: Incidents of Travel and Exploration in the Land of the Incas, New York, 1877 (Harper \& Brothers).

5 Véase Keith McElroy «Ephraïm George Squier: photography and the illustration of peruvian antiquities» En History of photography, 10 (2):99-129. 
Humboldt, cuyos estudios han de haber sido parte de su formación universitaria. ${ }^{6}$ Nunca llegarían a la emblemática isla volcánica, seducidos por la Cordillera de los Andes y su gente, permanecen en Sudamérica durante nueve años. En forma progresiva sus intereses comienzan a volcarse hacia otras disciplinas, coleccionando así, además de material geológico, objetos de distintas culturas, tanto arqueológicos como etnográficos. Siendo su obra más destacada: Das Todtenfeld von Ancón in Perú publicada en 1879 con el financiamiento del Museo Real de Etnología de Berlín. La misma consta de 141 litografías color, de alto valor, no solo artístico sino también científico. ${ }^{8}$ Muchas de éstas han sido realizadas por pintores profesionales en Alemania a partir del modelo directo, copiando los cientos de piezas que los viajeros se llevaron a su país. Desconocemos si se han realizado algunas ilustraciones a partir de fotografías, pero es muy posible que las imágenes de paisajes y/o plantas arquitectónicas pudieran haberlo sido.

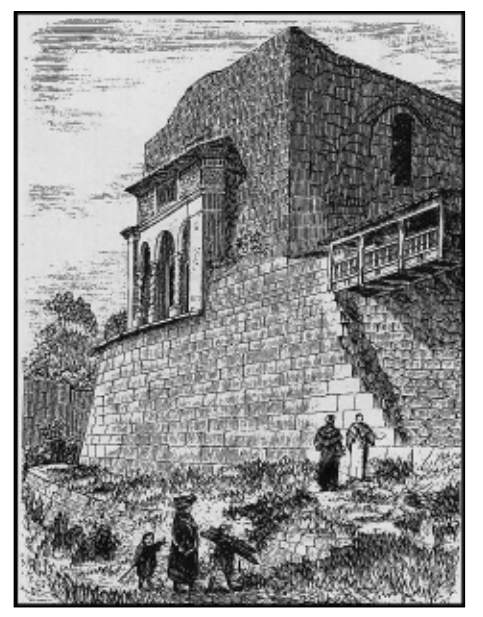

1. Muro terminal del Templo del Sol, Cuzco.

Stübel y Reiss, en menor cantidad, ${ }^{9}$ coleccionaron fotografías durante su estadía en América. La Colección Alphons Stübel cuenta con más de 2000 fotos y forma parte del acervo del Leibniz-Institut für Länderkund, en Leibniz. Es según señala Frank Stephan Kohl (2000: 1), la colección de fotografías de América del Sur del siglo XIX más importante de Alemania y probablemente de Europa. Los avatares de dicha colección han sido detallados por este investigador, quien informa que la misma se hallaría en proceso de digitalización. Al respecto refiere Andreas Brockmann: ${ }^{10}$

6 Stübel sería muy crítico, años después, de la obra de Humboldt, como lo señalara Scharader en su artículo: "Alphons Stübel, el hombre experto. Anotaciones a sus impresiones sobre los habitantes de Suramérica» (Tras las Huellas, dos viajeros alemanes en tierras latinoamericanas).

7 Según nuestra traducción El cementerio de Ancón en Perú.

8 Comparables en calidad con las acuarelas que años después realizara en Perú, Don Pedro Rojas Ponce, ilustrador y estrecho colaborador del Dr. Julio Tello.

9 La colección de fotografías de América del Sur Wilhelm Reiss es inferior a la de su colega. Inicialmente de alrededor de 800 fotos, 551 son idénticas o similares a las de la Colección Alphons Stübel. La misma pertenece al Museo Reiss, en Mannheim, Alemania.

10 En el capítulo titulado «Las sociedades latinoamericanas vistas por Stübel y Reiss», en Tras las Huellas, dos viajeros alemanes en tierras latinoamericanas. 
Las fotografías están organizadas de forma tal que permitan ofrecer una información general de la geografía y de la vida social de Suramérica. Al lado de las escenas urbanas, de los paisajes, etc., muchas muestran hombres de Latinoamérica, cuyas fotografía casi todas están pegadas a grandes planchas. La reordenación y los rótulos de estos documentos dan una explicación de determinadas estructuras de las sociedades que ellos deseaban describir.

Dentro de la colección, señala Kohl, se conserva un recibo de compra de 120 fotografías, constando en el mismo el precio pagado a Ricardo Villalba en Arequipa. La adquisición no solo comprende fotos del renombrado fotógrafo arequipeño, sino también material de Villroy Richardson y del atelier de Rodrigo \& Cía.

El amplio epistolario de Stübel y de Reiss ha sido analizado por distintos autores en las últimas décadas, destacamos a Juan Guillermo Gómez y a Ingrid Hönsch. En sus cartas, los viajeros, dejan demostrado su interés por el americano y sus costumbres, las que muchas veces rechazan, en especial Stübel. Es por ello que es llamativo que no tomaran sus propias fotografías y hayan recurrido a fotógrafos locales para sustanciar sus colecciones. Si un carácter sobresale de la colección de Stübel, es que en una gran cantidad (no podemos hablar de mayoría pues no hemos tenido acceso al corpus total) se trata de fotos de individuos, principalmente indios, pero hay sacerdotes, funcionarios, gauchos, damas de sociedad entre otros retratados. ¿Existía un carácter selectivo en los coleccionistas germanos o adquirían el material que los estudios y profesionales de la época les ofrecían? Es por demás interesante la cuestión y nos queda abierta para considerar en un trabajo futuro.

La dominación española había limitado el ingreso de extranjeros a los territorios andinos, siendo esta una de las razones por la cual los estudios no hispanos de las sociedades indígenas locales, se vieron postergados hasta después de los procesos de Independencia sucedidos en el siglo XIX y la caída del régimen colonial (Riviale, 2003: 541). No olvidando que, pese a estos obstáculos políticos, fueron expedicionarios pioneros en la región entre otros: Alexander von Humbodt, Alcide d'Orbigny y Paul Marcoy. Estos dos últimos, de nacionalidad francesa, han de haber sido motivación para el viaje que emprendiera en 1875 a Los Andes, su compatriota Charles Wiener. Su obra cumbre publicada en 1880 Pérou et Bolivie. Recit de Voyage contenida en un grueso volumen que consta de 1100 grabados. El éxito de su trabajo le permitió ser condecorado por su gobierno con la Legión de Honor y nombrado representante diplomático en Ecuador. Pascal Riviale (2003) señala en su texto, significativamente titulado "Charles Wiener o el disfraz de una misión lúcida", que el gran número de piezas coleccionadas llevadas a Francia, sus conferencias y publicaciones, así como la reconstrucción de monumentos y paisajes pintados del Perú prehispánico, hechos para la exposición de misiones científicas en París, en 1878, contribuyeron para construir una imagen idealizada del ilustrado viajero. Llegando a creerse que habría actuado solo, «animado por un don milagroso para encontrar rápidamente datos y especímenes arqueológicos» (539). Este mito se habría construido inicialmente por la ausencia de citas de colaboradores por parte de Wiener. En este caso, al igual que referimos anteriormente al tratar la cuestión de las fotografías sobre las que se realizaran los grabados en los textos de Squier y de Stübel/Reiss, es poca la información que al respecto se dispone. La ausencia de referencia a los fotógrafos habría sido una invisibilidad voluntaria al servicio de exaltar las cualidades mistificadoras del francés. Señala al respecto Riviale que algunas de esas fotografías fueron adquiridas a fotógrafos locales, en Perú a Ricardo Villalba y los hermanos Courret y en Bolivia a Georg von Grumbkow (Majluf, 2000: notas 21 y 27; Krauskopf, 2002: 113). 
Hace poco Gunther Krauskopf ha publicado en La Paz un libro dedicado a tres viajeros en Bolivia (Falb, Wiener y Ber), donde demuestra cómo Wiener usó, sin citarlo, fotografías que fueron tomadas por el ingeniero Georg von Grumbkow, cambiando las referencias para ubicarlas en un contexto imaginario. Krauskopf cita la anécdota de la Virgen de Copacabana que Wiener pretendió fotografiar. En el ejemplar del libro de Wiener que perteneció a Alphons Stübel, este había apuntado «mentira, es una fotografía de Grumbkow». ¡El lo sabía muy bien porque había comprado esta misma foto al ingeniero austriaco! (Krauskopf, 2002: 113).Seguro que Wiener no es el único que ha recurrido a tales compras. Fue probablemente una práctica común entre los viajeros que deseaban recolectar rápido material iconográfico y científico: se sabe que varios viajeros (Ber, Stübel, Falb) han comprado las mismas fotografías de Grumbkow (545).

Squier, Stübel/Reiss y Wiener, representantes de Estados Unidos, Alemania y Francia respectivamente, son algunos de los tantos viajeros extranjeros que a fines del siglo XIX recorrieran el Perú y Sudamérica. Tres visiones de lo andino construidas desde la concepción de lo diferente, lo nuevo, lo exótico. Sin desprenderse de tácitas consignas imperantes desde las crónicas del siglo XV y alimentadas por los estigmas de la ilustración. Aquellas en las que el hombre americano constituía una alteridad que debía reforzar los valores de occidente, "un otro» que debía subordinarse a las categorías de los viajeros y sus lectores. El buen salvaje, aquel bárbaro bueno que aún no conocía los beneficios de la cultura occidental y que en su ignorancia oscilaba entre conductas brutales y destellos de genialidad, podría, subordinado a los nuevos cánones, mejorar su condición. Este principio a la vez reposicionaba al modelo occidental entre sus modelados, otorgándole un carácter reinvindicador, normativo y ejemplificador. La norma se aggiorna a las necesidades de un insaciable imaginario que simultáneamente se nutre en su ejercicio impositivo.

Entre los años 1903 y 1904 arriba al altiplano boliviano «la misión científica francesa» de G. de Créqui Monfort y Sénéchal de la Grange. El Doctor Arthur Chervín es el autor de la obra en tres tomos, titulada Antropologie Bolivienne, publicada en París en 1908, que documenta esta investigación. Chervín, como señalan Giraudo y Arenas, "no salió de su gabinete en París pero fue responsable de trabajar con los materiales antropométricos de la expedición, es decir el suyo fue un trabajo de laboratorio» (2004: 129). Seguidor acérrimo de los principios antropométricos de Alphonse Bertillion ${ }^{11}$, quien estuviera a cargo del servicio de identificación de la prefectura de París, afirma en la introducción del Volumen I «Etnología, demografía y fotografía métrica», en el ítem titulado Photographie métrique: "Porque uno no se debe cansar de repetir que una fotografía no métrica es como un mapa geográfico del cual se ignora la escala» ${ }^{12}$ (Chervín, 1908: XXII).

En cuanto a lo que sucedía en la capital peruana, refiere Herman Schwarz (2007: 39) que la primera llegada de un daguerrotipo a Lima sucedió en 1842 y a partir de ese momento una serie de fotógrafos franceses inicia su trabajo en el Perú, destacándose entre ellos Philognie Daviette, Furnier, A. de Lattre, Amic Gazan y Emile Garreaud. El negativo de vidrio o coloide húmedo comienza progresivamente a desplazar al daguerro-

11 Creador del denominado Bertillonage System, método que conjugaba los principios antropométricos con la fotografía métrica. Bertillon diseñó un equipo compuesto por un silla tabulada y una serie de instrumentos (espejos, metros y compases) alineados con el objetivo de la máquina fotográfica. Su uso, adaptado a los avances técnicos, se continuó hasta mediados del siglo XX, como lo demuestran los registros del trabajo de campo de Bórmida e Imbelloni en Argentina.

12 Traducción del francés gentileza de Yvonne Casabonne. 
tipo siendo su principal mérito el permitir hacer varias copias de una misma imagen (a diferencia del daguerrotipo que es única). Es Garreaud quien impone el avance.

Francia no solo es la cuna de la fotografía sino también quien llevaba la delantera en los avances tecnológicos en la materia, así también en la popularización de la fotografía. Comienzan a instalarse los estudios fotográficos, destacándose el de Nadar en París, del que años después se abriría una sucursal en Lima, a cargo de Eugene Maunoury, quien popularizara, según Schwars, la «tarjeta de visita», la cual causaría entre los limeños una gran revolución. Tal fue la repercusión que llevó a los entendidos a llamar a este momento «la era de la tarjeta de visita». ${ }^{13}$ Cualidades únicas e inmensamente enfrentadas acarreó la invención de este formato. Su bajo costo y acelerada popularidad lo llevaron rápidamente a convertirse en una necesidad social imperativa, frente al coleccionismo aristocrático y burgués que, cual objeto de deseo, buscó conservar lo intangible del ahora otorgando cierto estatus social a un objeto intercambiable y coleccionable.

Fotógrafos nacionales y extranjeros comenzaron a construir un nuevo imaginario del Perú respondiendo a diferentes intereses y necesidades. Referiremos solo unos pocos ejemplos antes de adentrarnos específicamente en la cuestión cusqueña. ${ }^{14}$

Manuel Atanasio Fuentes, un peruano multifacético nacido en Lima en 1820, pudo reparar en el poder que tenía la imagen y buscó darle utilidad en pos del estado nacional. Registrar a los presos para «resguardar a la sociedad de su presencia», darle al gobierno una herramienta para comunicar de una manera directa y rápida, y ejercer el control de manera efectiva. Fue uno de los principales protagonistas en intentar difundir una imagen distorsionada del Perú. Un proyecto nacional que negaba al indio, que miraba hacia Europa, contribuyendo a la imagen de una Lima estereotipada que hasta hoy arrastra sus rezagos. Fuentes, en su obra Lima, lega una muy particular visión de la realidad social del Perú. Manipula y ordena las imágenes de su libro omitiendo el protagonismo del indio ante el del blanco. Este hecho lleva relación con las tapadas limeñas (mujeres que cubrían su rostro), símbolo de la negación del otro. Taparse para no ser confundido, ocultando un provocativo misterio frente a las represivas estructuras sociales de la época.

El desarrollo del ferrocarril fue registrado por diferentes profesionales, entre los que destacan el francés Eugéne Courret (dueño, junto con su hermano Aquiles, de uno de los más importantes estudios limeños de la época), el estadounidense Benjamin Franklin Pease y el peruano Ricardo Villalba. Este último, quien instaló uno de sus principales estudios en Arequipa ca. 1870, se diferencia de sus otros dos colegas por no solo haber registrado lo ferroviario como desarrollo ingenieril, sino por ocuparse de contrastar estos elementos representativos de la modernidad con aquellos tradicionales de la cultura de su país (Majluf, 2001: 84), rescatando valores muy poco difundidos en la Lima decimonónica. La sociedad limeña blanca, aristocrática y europeizante; negaba, rechazaba toda vinculación con los valores autóctonos y por ende con «lo indio».

¿Cuál fue la bisagra que unió a Lima con el resto del Perú?, ¿fueron las nuevas vías de comunicación, tomando la imagen del ferrocarril como símbolo del progreso? ¿Fue el ideal de integración nacional o los primeros viajeros que recorrieron el Perú, los que unieron el territorio nacional; o acaso también las imágenes y publicaciones sobre el registro

13 Majulff se refiere al periodo comprendido entre 1859 y 1879 (2001: 38).

14 La RAE sostiene que tanto Cusco y Cusqueña son escrituras válidas en Perú, aunque «Cuzco es la más extendida en el conjunto de los países hispánicos», esto considendo que en el idioma quechua no existe el fonema «z» (Nota del editor). 
territorial y documental que fueron dando luz a las tierras andinas negadas y olvidadas? Majluf señala que «la colonización de la sierra por la tecnología moderna implicaba una estrategia de integración del indio a la nación, una misión civilizadora que lo rescataría de la postergación y el estancamiento en que supuestamente se encontraba» (2001: 85).

¿Qué rol desempeñó la fotografía en este proceso?

Emile Garreaud fue uno de los extranjeros que más contribuyó a crear un nuevo imaginario del peruano, incluyendo imágenes de un Perú indio, rural, andino. Su labor profesional se desarrolló también en Chile, abriendo estudios en Santiago, Copiapó y Valparaíso, donde registrara múltiples escenas costumbristas y campesinas (Rodríguez, 2001: 103-8).

Ejemplo de lo expuesto es la imagen que ilustra este texto (lámina 2). Sus protagonistas, cuatro campesinos andinos que son reconocidos por la vestimenta que llevan: monteras, pantalones y ponchos probablemente de la provincia de Canchis, distritos de Tinta (Cusco). Este tipo de montera ha variado y adoptado otras formas. Los pantalones y los ponchos se pueden ver en la actualidad en esta zona con algunas variantes. Las sandalias que calzan tres de ellos son de cuero, probablemente de llama. Hoy ya no se producen, fueron totalmente reemplazadas por las ojotas de caucho. Otro dato que puede ayudar a afirmar que son personas de esta zona son los vasos de Chicha, característicos de Cusco y no de la Puna ni del Altiplano ${ }^{15}$. La Chicha (Aqha en quechua) es una bebida ancestral del Perú que se prepara a base de maíz fermentado. Esta bebida acompaña tanto una jornada de trabajo en la chacra, un momento de descanso o una tarde de conversación, como también eventos más trascendentes: pagos a la tierra y ceremonias a los Apus (deidades andinas).

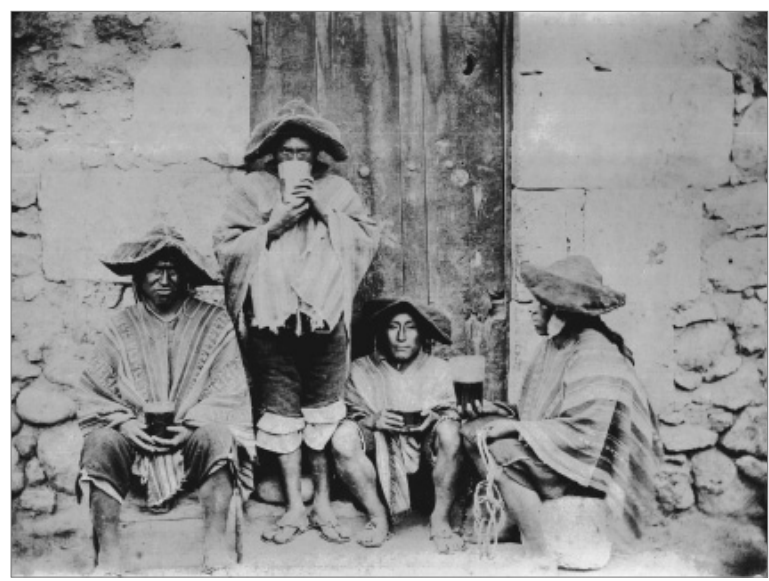

2. Emile Garreaud, Indígenas de Cuzco. Albúmina, ca. 1862. Gentileza Archivo Cuarterolo.

Los retratados no dejan de beber su chicha pareciendo no interpelarse frente al fotógrafo. Miran pacíficamente a aquel sujeto extraño que con un inmenso aparato los apunta. ¿Cuál sería la intensión del fotógrafo? Antiguamente con las cámaras de gran tamaño era muy difícil sorprender al objetivo y retratarlo, suponemos requería de un cierto permiso de parte de quien sería capturado. ¿Quién sabe si Garreaud astutamente,

15 Agradecemos al Dr. Jorge Flores Ochoa por los datos que nos aportara en esta lectura. 
invitó a estos campesinos a tomarse una chichita a cambio de un registro etnográfico semejante?

En 1869, en Chile nace Fernando Garreaud, hijo de Emile, quien, emulando el trabajo de su padre, ${ }^{16}$ diera a conocer en vísperas del comienzo del siglo veinte su obra más relevante. Se trata del álbum República Peruana 1900, constituido por 495 fotografías, abarcando una visión amplia del Perú, su gente, su historia y sus paisajes.

La difusión de este material (se habrían editado 1000 ejemplares, de los que se conservarían, a la fecha de este escrito, solo dos) ${ }^{17}$ como el surgimiento de fotógrafos nacidos en territorio peruano dieron origen a la construcción de una nueva imagen del Perú. Antes de adentrarnos en la producción fotográfica del Cusco, no queremos dejar de citar al fotógrafo y estudioso alemán Heinrich Brüning, ingeniero de profesión, quien logró captar la vida y costumbres del pueblo Muchik con objetividad y relativismo cultural (Schaedel: 1998: 10). Precursor de la fotografía antropológica en Los Andes, no solo hizo registros visuales sino también sonoros, estudiando la música del norte del Perú y elaborando además un diccionario de la lengua mochica. ${ }^{18}$

\section{EN LOS AVATARES DEL PROGRESO, INCANISMO E INDIGENISMO}

La guerra del Pacífico (1881-1883) ${ }^{19}$ marcó una notable disminución en la actividad fotográfica de Lima. Luego vino la etapa de reconstrucción de un país destrozado. Comienza el ciego camino hacia el progreso, el llamado "gran proyecto nacional».

Se inicia el auge de la fotografía de provincia, a partir de 1875 se realizan los primeros registros del sur andino. Luis Alviña, Miguel Chani, Luis D. Gismondi, José Gabriel Gonzales y Juan Manuel Figueroa Aznar, sembraron los primeros pasos de una brillante generación de fotógrafos en Cusco. Como señala Majluf, "Chani da inicio al apogeo de la fotografía cuzqueña» (2001: 94). Luego devino una importante generación de fotógrafos cuzqueños, la cual sería bautizada por el historiador Pablo Macera como: Escuela cuzqueña de Fotografía (Benavente, 1995: 8). Además de los referidos integraban el grupo entre otros: Martín Chambi, Crisanto Cabrera, César Meza, Eulogio Nishiyama, Horacio Ochoa, David Salas, Fidel Mora, Pablo Veramendi y Avelino Ochoa. Una de las diferencias entre ellos fue marcada por el tipo de clientes con los que trabajaban, ya sean los de la elite cuzqueña, que requerían ciertas condiciones y exigencias, como la fotografía más modesta de los estudios precarios en las comunidades. Tenían en común formar parte de una gesta fotográfica que alcanzó grandes niveles de desarrollo estético y documental. La prensa comienza a propagar y difundir la imagen del interior del país, una revista como Variedades, requieren de fotógrafos permanentes para publicar sus nú-

16 Emile Garreaud publicó en Valparaíso (Chile) en 1869, un álbum con 22 fotografías de gran formato titulado Vistas de la Patagonia del Estrecho y de la Tierra del Fuego.

17 Uno en la Biblioteca Nacional y otro en el Instituto Raúl Porras Barrenechea, ambos en Lima, Perú.

18 El legado científico de Brüning está preservado actualmente en el Museo Nacional de Arqueología y Etnografía que lleva su nombre, en la ciudad de Lambayeque, Perú, (en cuyo archivo fotográfico habría más de 2000 fotografías), así como en el Museo Etnológico de Hamburgo y en el Museo Etnológico de Berlín (Alemania).

19 Conflicto armado entre Chile y la alianza Perú-Bolivia por intereses económicos y territoriales. 
meros con un alto contenido de imágenes. El retrato, el autorretrato, los tipos indígenas (idealizar al indio o documentarlo), los vestigios arqueológicos, los paisajes citadinos, son muchos de los temas que se desarrollaron en el sur andino.

En 1909 se produce en Cusco la primer huelga universitaria en el seno de la Universidad Nacional San Antonio Abad, movilizada por la necesidad de una reforma eminente de sus arcaicas estructuras. Participan allí estudiantes, como refiere Kuon de la llamada «generación de La Sierra o generación de 1909» (2009: 36), que luego serían la base de la intelectualidad y del futuro social del sur andino, pilares del fenómeno del «indigenismo» cusqueño. En 1927 se produjo una segunda protesta surgida también en el seno de la UNSAAC, en reclamo de una reforma universitaria. Juan Carlos Gutiérrez, en su libro La generación cuzqueña de 1927 enuncia que:

El indigenismo plástico de los años veinte, de manera similar al indigenismo literario contribuyó a crear el sentimiento de identidad americanista, la coincidencia de una voluntad creativa que, sin renunciar a las vanguardias artísticas europeas, encontró nuevas formas de expresión incorporando el paisaje y los pueblos andinos con sus costumbres y tradiciones laborales y festivas (2007: 55).

Destacan Luis E. Valcárcel, autor de una de las obras más influyentes del movimiento: Tempestad en los Andes, publicada en 1927, y Uriel García, autor de El nuevo indio, tres años después. Ambas obras disputaban valores encontrados. La primera declara que la "pureza de la raza» reside en el no ser mezclado con la sangre del invasor, mientras que la segunda postula lo contrario, donde los valores del mestizo son justamente la potencia que habría generado el «mejoramiento de la raza» (Poole, 2000: 225).

Sobre el indigenismo, término que abarca diversos conceptos y pensamientos, Elizabeth Kuon señala:

Este movimiento nunca fue un fenómeno homogéneo ni representó una corriente de pensamiento con clara perspectiva de clase. Más bien, las clases sociales de entonces intentaron formular algunos planteamientos ideológicos sobre los problemas nacionales, dentro de los cuales, el problema del indio, era cuestión fundamental (2009: 39).

En 1911, el «descubrimiento» de Machu Picchu pone al Cusco en el candelero mundial. A partir de allí se comienza a ver al pasado incaico como un ideario de perfección e igualdad social. Se consolida así el «incanismo» ${ }^{20}$. Se publican las primeras guías turísticas que buscan mostrarle al visitante las maravillas del Perú. En 1925 aparece la primera del Cusco, Guía Histórica Artística del Cusco de Uriel García, Luis Valcárcel y Alberto Giesecke. En 1934, Cusco Histórico, homenaje a la ciudad de todos los tiempos de Rafael Larco Herrera, con fotos de Chambi y Figueroa.

Con respecto al concepto de «incanismo», el Dr. Jorge Flores Ochoa escribe: «mentalidad cuzqueña, sea cual fuere su ubicación social, grado de instrucción, u otras consideraciones sociales y culturales, [...] se halla presente el sentimiento de identidad con lo inca, con las glorias reales o supuestas del Tawantisuyo". Señala el autor, que este sentimiento compartido por los cuzqueños es atemporal, deviene según sea evocado, «tiene presencia y continuidad» (1990: 11-2).

20 Tamayo Herrera lo nombró «incaismo» y Flores Ochoa «incanismo». El origen de incanismo se remonta a la época colonial con el libro de Garcilaso de la Vega, Comentarios Reales de los incas, obra que inspiró a los grandes levantamientos indígenas (Kuon, 2009: 40-1). 
Los fotógrafos cusqueños de la época y sus obras antes y durante el movimiento indigenista, constituyeron la razón convocante para la realización de este artículo. Nos encontramos, mientras comenzamos a elaborarlo, con una serie de dificultades que entendemos necesario aclarar. Es muy poca la bibliografía referida al tema, siendo los textos de Deborah Poole fundamentales, como así también los trabajos de Adelma Benavente. Son escasos los datos biográficos de muchos de sus protagonistas, por lo que debimos entrevistarnos con sus familiares o allegados.

Hemos contado con la colaboración de estudiosos del tema, quienes desinteresadamente nos brindaron valiosa información. Avanzado el proceso de elaboración del material, nos dimos cuenta de que solo podríamos, en esta instancia, contemplar la producción de unos pocos fotógrafos, dejando para una posterior el resto de la investigación.

\section{EN EL RETRATO DE UN RETRATADOR}

César Meza nació en 1912, en Huancasancos, Ayacucho. En 1929 se trasladó al Cusco y allí se dedicó principalmente a la realización de retratos e imágenes de estudio. También hizo fotografías en exteriores creando un rico testimonio de la historia regional. «Retratista por convicción», así lo nombró el periodista Fernando Vivas Sabroso (1992: 61), en una nota publicada en la revista Caretas en un homenaje que se realizó a los últimos sobrevivientes de la Escuela Fotográfica del Cusco. El «Retrato de Campesino» (lámina 3) como imagen emblemática del andino, fue recientemente utilizado como póster de la muestra fotográfica Conservando miradas, organizada por la Fototeca Andina de Cusco, para celebrar sus primeros 20 años de actividad ${ }^{21}$. Meza es reconocido por sus retratos de estudio y es muy probable que esta fotografía haya sido tomada en su estudio, por la iluminación, el fondo desenfocado y la aparente quietud del retratado. El rostro y actitud del campesino reflejan cierta reticencia frente a la cámara. La seriedad y el gesto firme permiten leer incomodidad y malestar, su mirada fija en la cámara podría interpretarse como increpando a quien lo observa, denotando oculta y permanente resistencia.

Como señala Margarita Alvarado, un primer sentido básico necesario de destacar y uno de los aspectos más trascendentales otorgados al traje y a la indumentaria, es su calidad de indicador social y étnico, porque relacionan al sujeto con diferentes y variadas realidades (2000: 138). En este caso, analizando el poncho y la montera podría tratarse de un poblador de la zona de Canchis, como nos acotara Nilda Callañaupa. En cambio, considerando el chullo (gorro) y la oqesa (manta para cargar), podría decirse que es de la zona alta de Calca.

El textil como lenguaje, es un medio para conceptualizar el mundo, representando en él ideas religiosas y objetos de la vida cotidiana (Trevisan, Málaga y Massa, 2002), el poncho, el chullo y la montera son indicadores de procedencia. El diseño de los mismos, muchas veces deja leer, para los conocedores de la simbología y del código textil: la región, el estado civil y jerarquía de quien lo porta. En Los Andes peruanos la vestimenta conlleva un sinnúmero de mensajes que permiten al propio y al ajeno, conocer y reconocer a través de símbolos, la identidad de quien la viste.

21 Expuesta desde el 20 de Abril al 22 de Mayo en la sede del CBC, Centro Bartolomé de las Casas, Cusco. 


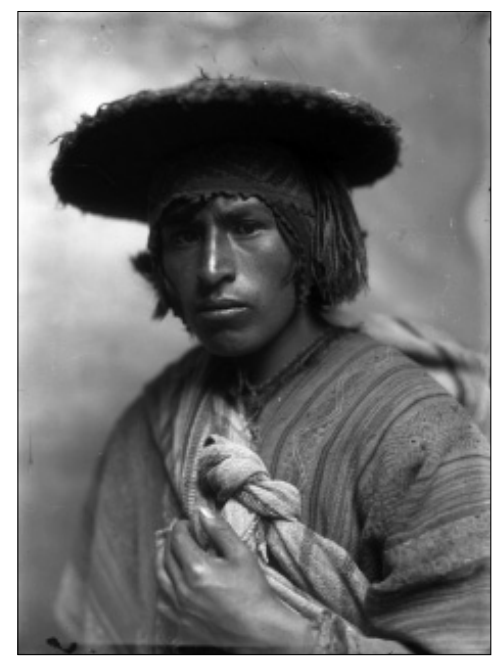

3. «Retrato de Campesino», César Meza, 1940. Fototeca Andina.

La imagen muestra al campesino retratado inmerso en el «efecto de indicernibilidad» (Alvarado: 139), entendiéndose por tal a la no diferenciación cuerpo/vestido, donde el traje actuaría como una segunda piel. Sujeto e indumentaria conforman un todo. La rigidez del cuerpo, de su mano, de su rostro, pueden tener que ver con lo que Susan Sontag escribiera acerca del acto de fotografiar, "todo uso de la cámara implica una agresión» (2006: 20-1).

Esta fotografía ha sido usada muchas veces como representativa de la andinidad, es una imagen que exalta la belleza y fortaleza del indio. Tomando en cuenta que fue registrada en 1940, pleno auge del movimiento indigenista en Cusco, se podría suponer que la intención del fotógrafo fue emblematizar y revalorarizar la visión del campesinado andino. La iluminación directa e intensa le da brillo a la piel bronce y resalta los rasgos del retratado.

La lámina 4 nos muestra un retrato de Don César, en el mismo podemos apreciar además de su cándida figura, las características del último estudio en el que trabajara. ${ }^{22}$ Posa junto a su máquina fotográfica y otros elementos técnicos, en el fondo el telón característico de muchos de sus retratos. La temática que desarrolló durante toda su carrera fue el retrato, como él declarara: "yo hago exclusivamente retratos». Esther Meza nos informó que su padre trabajó junto a Miguel Chani y Juan Manuel Figueroa Aznar, probablemente como colaborador y aprendiz. Nos contó, que el telón está "perdido» y seguramente muchos de los negativos de su padre están «alojados» en otros archivos. Las cámaras y parte del material fotográfico de Meza fueron vendidos por su hija al Instituto Guaman Poma de Ayala. El mismo artista en vida vendió parte de su archivo a la Fototeca Andina.

Meza, quien pasara una muy difícil infancia, ingresa con trece años en un taller de fotografía en Pisco, sin saber leer ni escribir. Luego viaja a Chincha Alta, en Ica, donde realiza sus primeros retratos. El 5 de abril de 1929 llega a Cusco acompañado de un amigo pintor, Salvatierra, con quien aparentemente se asoció para armar su primer estudio. Se casa con una cusqueña. En el año 1931 se une al partido del APRA, Alianza Popular Revolucionaria Americana. En 1936 fue preso durante catorce años, quizás con

22 Los datos son extraídos de la entrevista personal con Esther Meza, hija menor de Cesar Meza. 


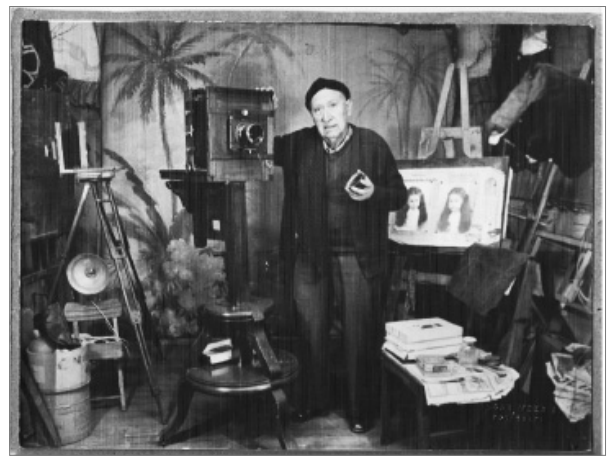

4. Sin título. César Meza en su estudio, gentileza de su hija Esther.

intervalos de libertad. Estuvo en la cárcel peruana el Sexto, donde también estuvo José María Arguedas. El infierno vivido en la cárcel lo llevó a Arguedas a escribir la novela El Sexto, publicada en 1961, y a declarar que la prisión es un lugar donde se puede encontrar desde lo peor de la sociedad hasta quienes lucharon incansablemente por cambiarla. Meza fue uno de estos últimos y durante su cautiverio tuvo la oportunidad de compartir con intelectuales, presos como él, compañeros que colaboraron con su instrucción tardía. Arguedas, uno de los mayores baluartes de la literatura peruana, trata a lo largo de sus cuentos y novelas, con incomparable maestría, las penurias y vicisitudes de sus personajes indios. Pero no fue éste el único contacto que tuviera Meza con la literatura indigenista, el primero de sus tres estudios cusqueños, ubicado en la calle San Francisco 310, fue la casa donde naciera Clorinda Matto, autora de la obra pionera del movimiento indigenista Aves sin nido.

César Meza tuvo una vida dura, murió pobre y enfermo, sin que su partido político valorara su trayectoria y esfuerzo. Hoy su hija sólo espera el debido reconocimiento para su padre, que muriera en Cusco en 1993. Valgan estos párrafos como humilde reconocimiento.

\section{SOY DE AQUÍ, SOY DE ALLÁ}

Martín Chambi nació en Coasa, Carabaya, al norte del gran lago Titicaca, en 1891. Murió en Cusco, en su estudio de la calle Márquez, en 1973. Su maestro fue Max Vargas, eximio fotógrafo arequipeño contemporáneo de Miguel Chani y de quien fueran discípulos también los hermanos Vargas (Carlos y Miguel).

Jorge Heredia señala que Edward Ranney, fotógrafo norteamericano, luego de conseguir apoyo de la fundación Earthwatch de Massachusetts en 1977, fue el primero en tomar la reorganización del archivo de Martín Chambi. En vida Chambi pudo exhibir sus trabajos en varias exposiciones tanto en el Perú como en Chile (Santiago y Viña del Mar), pero fue por la intervención que realizara Ranney y un grupo de voluntarios en el estudio de Chambi, luego de su muerte, que 15.000 negativos fueron limpiados y ordenados. Comenzando así la vida moderna de la obra de Chambi (Heredia, 1993: 149). La misma comienza a ganar espacio en Europa y Estados Unidos, convirtiéndose en la imagen más 
difundida de la fotografía cusqueña. Ranney señala que «Chambi se definió como un artista y documentalista fotográfico, arraigado en su pasado indigena [...] paradigma de la aculturacion exitosa» (2001: 134). Los grandes temas que abordó, fueron el retrato comercial, paisajes y vistas arqueológicas, documentación etnográfica y autoretratos. «El constante interés de Chambi en retratarse, tanto dentro como fuera del estudio, parece reflejar una permanente conciencia de su propio proceso de aculturación, así como su confianza y placer en representarse visualmente a lo largo de los años» (150).

En 1911, Hiram Bingham "descubre» Machu Picchu; un profesor norteamericano le muestra al Perú y al mundo una de sus riquezas más extraordinarias. De un momento a otro, todo lo olvidado y opacado por la luz de lo foráneo recobra su propio brillo. Cusco se ilumina ante las luces del reconocimiento, la revaloración y reafirmación de «lo auténtico». No precisamente porque Bingham lo propiciara, como señala Deborah Poole «su interés, empero, tenía más que ver con las posibilidades que le ofrecía la historia incaica para inscribir sobre la propia faz de Sudamérica su autoridad personal como explorador, que con los mismos incas» (1991:116). Sabía que allí existía un tesoro, inmenso, poderoso, y quiso ser él protagonista de semejante descubrimiento, a pesar de encontrar huellas de los que llegaron con anterioridad, los que lo llevaron hasta allí y «para sustentar sus pretenciones de que Machu Picchu estaba cubierto de siglos de maleza», nunca reprodujo ni publicó uno solo de sus numerosos negativos que muestran el trabajo de los indios (Poole, 1991: 118).

Chambi, al igual que sus colegas, se suma a ese creciente interés, que surge a partir de las noticias de Machu Picchu, por lo peruano y lo inca. Pero desde una perspectiva mucho más honesta que la del profesor de Yale.

En esta fotografia (lámina 5) Martín Chambi, en las alturas de Carabaya, pareciera alejarse de las raíces para polinizar su identidad en la agitada vida intelectual y cultural del Cusco de los años 20, caminando hacia el progreso. Junto a una mula, en un alto en el camino para registrarse, dejando su pueblo natal Coasa, por detrás. Su vestimenta denota las bajas temperaturas de las montañas andinas. La cámara con la que Chambi registró este "autorretrato" carecía de disparador automático, circunstancia que nos lleva a pensar que para poder realizarlo tuvo que contar con el apoyo de un asisitente que disparara el obturador. Quien lo haya hecho, posiblemente habrá seguido supuestas indicaciones del fotógrafo: que se vea mi pueblo entre la mula y yo, sube a esa piedra y ganarás perspectiva.

El vestuario con el que inicia su viaje, botas y sombrero por un lado y su poncho emblema de la serranía por otro, componen una indumentaria sincrética, expresión de lo Mestizo. Valor que podrá apreciarse como uno de los más representativos en toda su obra como fotógrafo.

La importancia de Chambi reside, más allá de su aporte estrictamente fotográfico, en el tipo de mestizaje, no biológico sino cultural, que el encarnó, donde se equilibran y enriquecen la sensibilidad urbana y la campesina, la visión quechua y la occidental, el impulso de modernidad y el reclamo de lo tradicional, la apertura a los valores del siglo XX y el anclaje en los valores del Perú prehispánico (Huayhuaca, 1992: 138).

Sin lugar a dudas, es el fotógrafo más conocido del Perú, no solo en su país, sino en el mundo entero. Mucho se ha escrito y publicado sobre su producción, seguramente su obra seguirá resultando fuente de inspiración para artistas e investigadores. Por eso 


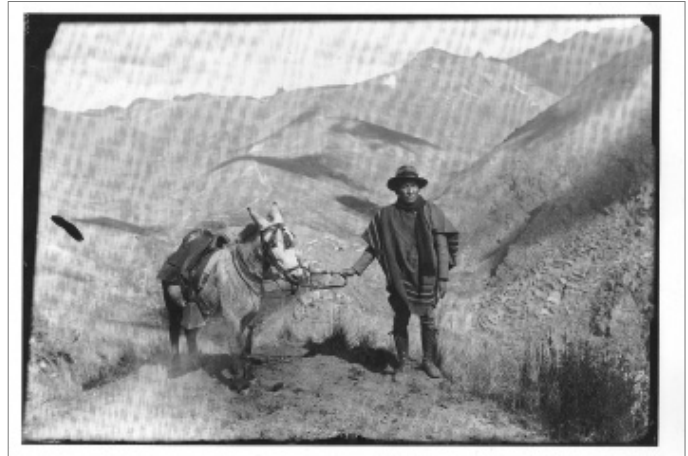

5. Foto: «Autoretrato en Coasa». Autor: Martin Chamba. Placa vidrio 10 x 15 cm. Año: ca. 1924/1930.

creemos pertinente considerar lo que plantea Jorge Heredia, respecto al señalamiento que hiciera manifiesto Michelle Penhall ${ }^{23}$ :

Hay un número aún no determinado de negativos en el archivo Chambi que no fueron hechos por él. Este hecho era conocido por los estudiosos y tiene raíz en la difundida costumbre de la época de transferir estudios de un fotógrafo a otro con todo su contenido, incluido negativos (1993: 162).

\section{¿EN QUÉ HONDONADA ESCONDERÉ MI ALMA PARA QUE NO VEA TU AUSENCIA...? ?24}

En el texto Hacia el despertar del alma india. Voces en torno al gran problema, publicado en Lima en 1929, se trata una serie de temas referidos al indigenismo (El Indio en la vida nacional, El problema del Indio, El problema del indio y de la tierra). Abre el libro una nota liminar firmada por Rafael Larco H. seguida por el artículo del Dr. Luis E. Valcárcel, titulado «Ideario" y que habría sido extraído de su obra Tempestad en los Andes ${ }^{25}$. Ilustran la edición 41 fotografías, incluyendo la portada y un mapa del Tahuantinsuyo. Lo relevante, en relación a nuestro artículo, es que no aparecen fotos de indios, salvo en algunas imágenes de ruinas, donde con intención de parámetro métrico se observan figuras humanas, la presencia del sujeto en cuestión denota una llamativa ausencia. En la tapa (lámina 6) se observa la imagen de un rostro humano de frente y en la página 25 el mismo, pero de perfil, se trata de una escultura del artista español de Ramón Mateu. Al pie de la misma se lee «...acusa en sus líneas la grandeza del alma de la raza. Es el Amauta, el pensador, el sabio, el celoso depositario de la cultura del gran pueblo». En la página 33 se

23 Fotógrafa e investigadora independiente (quien realizara su tesis de doctorado sobre Martín Chambi) manifiesta en una charla que dictara en Nueva México titulada «Martin Chambi: The reassesment of a Legend »: en el marco del FOTOFEST 1992.

24 Verso extraído del poema «Ausencia» de Jorge Luis Borges.

25 Publicado en 1927, es considerado el primer manifiesto indigenista del Perú. José Carlos Mariátegui al prologar la primera edición señala «La empresa de Valcárcel en esta Obra, si la juzgamos como la juzgaría Unamuno, no es de profesor sino de profeta». 


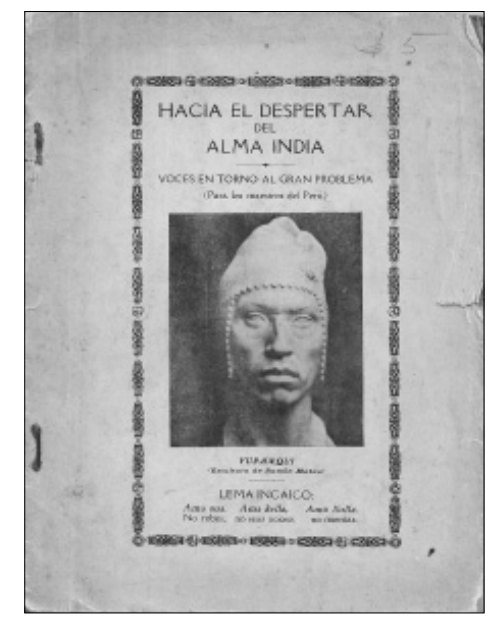

6. Tapa del libro Hacia el despertar del alma india.

puede observar a una mujer desnuda de rasgos occidentales, que sostiene entre sus brazos a un joven. También es una escultura, en este caso atribuida al artista cusqueño V. Delgado y titulada «La madre de Huáscar presiente el desastre del Imperio». ${ }^{26}$

El resto de las fotos muestran ruinas arqueológicas, piezas cerámicas ancestrales, paisajes, calles, iglesias y edificios.

¿Por qué no hay fotos de indios, de individuos, grupos, actividades sociales, domésticas o cualquier otra imagen que muestre a quien hace referencia el libro? Se trata de una obra escrita en pleno desarrollo del movimiento indigenista y es justamente Valcárcel uno de los abanderados de dicha ideología. El «despertar del alma india y el gran problema del indio» nos interpelan desde una relativa ausencia de imagen, desde una alternativa imaginaria, que como señala Pedro Mege, no se trata de negación, ni de una estrategia de ocultamiento, pareciera ser un lapsus, donde se sucede un desplazamiento del significante: imagen de indígena por sus ruinas; se lo relega a un fuera de marco, por un nuevo referente: las ruinas que significan lo indígena. Entonces, se ha expresado lo indígena en un significado fetichizado, en una materialidad deseada (2009). ${ }^{27}$

Pareciera no con-decirse el discurso pro-indio de los autores con ninguna imagen contemporánea al texto, como si la imagen coetánea del indio no revelase el correlato buscado, en tanto presencia. Un paradigma de la idealización donde lo no visto reemplaza a lo visible.

\section{CHICHA Y LIMONADA}

Miguel Chani, nacido en 1860, en la provincia de Quispicanchis (Cusco), fue autodidacta y considerado uno de los fundadores de la escuela cusqueña de fotografía junto con José

\footnotetext{
26 Huáscar pelea con su hermano Atahualpa en 1532, situación que aprovecha Pizarro y sus soldados para derrotar al «imperio Inka».

27 En Viviendo en un mundo material en imprenta.
} 
Gabriel Gonzales, Juan Manuel Figueroa Aznar y Luis D. Gismondi. Llegó a tener tres estudios simultáneos: Puno, Arequipa y Cusco. Este último en la calle Márquez 67, que luego fuera tranferido a Manuel Figueroa Aznar y de éste a Martín Chambi.

Gentileza del archivo Benavente nos es cedida la fotografía de la lámina 7, bajo el título "Mujer indigenista con aríbalo». La foto habría sido tomada, según la información que nos proporciona la Sra. Adelma Benavente, por Chani en 1915.

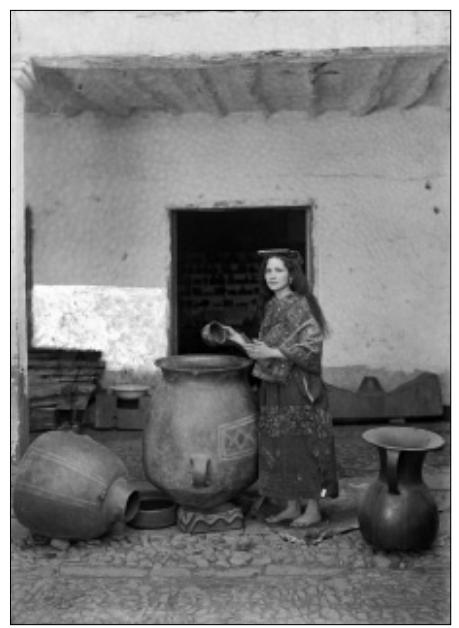

7. Miguel Chani. Año: ca. 1915. Fuente: colección Adelma Benavente.

El escenario es el patio del antiguo local del Museo Inka (anteriormente llamado Museo Arqueológico del Cusco) sito en la calle San Andrés, hoy residencia privada. La vestimenta de la mujer no corresponde a la vestimenta de una Colla Inka. Es un "particularísimo» intento de mostrar el atuendo de una mujer inca.

En la cabeza tiene puesto, a modo de ñañaca (prenda textil prehispánica de uso cefálico), un tapiz colonial doblado en varias partes. Como lliqlla (manta para cubrir la espalda) lleva otro tapiz colonial que no corresponde al uso como lliqlla. Porta un Tupu (prendedor o sujetador) inca para sostener la pieza. Debajo de este tejido se puede ver otro textil colonial. La falda es un $u n k u$ (camisa masculina) inca de transición. ${ }^{28}$ En la imagen se puede observar el unku completo, hoy el museo sólo cuenta con una parte la posterior (por lo que deducimos de los tokapus, código gráfico), la que se luce al frente aparentemente está en Colonia, sin que haya registro de cómo llegó a Alemania. Nótese la presencia de la etiqueta identificadora de la pieza perteneciente a la colección del museo, en el borde inferior del $u n k u^{29}$.

Detrás de la mujer a mano derecha se puede observar un molino de piedra colonial, hoy se exhibe en el patio de los almacenes del museo. Del lado izquierdo hay una piedra de diorita verde, finamente trabajada, probablemente parte de una acequia o de una paccha (fuente ritual). Sobre esta piedra una palangana de época de la toma.

28 Se denomina «de transición» a aquellas piezas manufacturadas entre 1532 y la instauración definitiva del régimen colonial.

29 Las piezas arqueológicas que se observan en la composición fueron cedidas por el Museo Arqueológico de Cusco y salvo la excepción señalada siguen formando parte de dicha colección. 
Las cerámicas que se observaban, de derecha a izquierda de la imagen, en primer lugar una "ánfora», vasija inca expuesta hoy en la cancha el museo. Al centro de la imagen, al igual que el urpo, recipiente utilizado durante el incario para fermentar chicha, bebida a base de maíz como señaláramos al referirnos a la lámina 1. Antonia Miranda, quien fuera directora del Museo Inka y que gentilmente colaborara con nosotros en este análisis, señala que los diseños del urpo corresponden al tipo C, basándose en la clasificación que hizo John Rowe de la cerámica inka. La mujer en su mano derecha lleva una ollita, objeto que no corresponde para la función que aparenta realizar, la de extraer la chicha del urpo. A la izquierda, echado, un aríbalo (cerámica inka), con aplicación de un puma. Bajo el urpo, a la izquierda una fuente circular, utilizada probablemente para medir antiguamente niveles de agua en la construcción. Junto a ella un mortero ceremonial, con un diseño de Amaru, serpiente cósmica. La mujer está parada sobre un cuero de puma, se observa una puska (instrumento para hilar) y un ovillo. A sus espaldas se puede ver una habitación con piezas de la colección del museo. Al fondo de la imagen, a mano derecha se observa una mancha extraña en la pared. Debajo se observa material acumulado, lajas o maderas. Si uno se detiene allí y observa con detenimiento, «saldrá a la luz» una figura humana masculina que adrede se ha querido borrar de la imagen.

Los cítricos fueron introducidos en América tras la conquista y la limonada, preparación hecha a base de limón, azúcar y agua, se transformó en bebida de la colectividad blanca de Lima desde épocas coloniales. Chicha de los indios, limonada de los blancos. Dice el dicho popular, en relación a lo que no es ni una cosa ni otra: "Ni chicha ni limonada». En este caso entendimos oportuno el jugar con las palabras para titular este segmento, como jugó con la vestimenta en la composición quien la haya realizado. Tenemos nuestras dudas respecto a la autoría de la misma. Chani era un profesional de la imagen, ¿cómo es que compuso esta fotografía? ¿Fue su intención generar un ridículo personaje armado con piezas de museo distorsionadas? ¿Construyó adrede un icono de lo absurdo? ¿Quiso jugar con el humor? ¿Y la presencia del personaje que posteriormente se intentó borrar? Incluyendo en este cuestionario las preguntas que nos propone Margarita Alvarado al respecto: "¿realmente el hábito hace al monje?, ¿qué pasa cuando los códigos y normas propios de determinados códigos en relación al traje y la indumentaria son violados, cambiados, intervenidos o manipulados?» (2000: 140).

Como corolario de la figuración y desfiguración que genera esta imagen en el tiempo es válido recordar que en junio del 2005 se utilizó esta fotografía para ilustrar un taller de museología, que paradójicamente se dictó en el Museo Inka, llamado La voz indígena en los museos.

\section{ALMA INCÁNIDA}

Juan Manuel Figueroa Aznar fue un artista multifacético. No solo fue fotógrafo, pintor y actor, sino también activo protagonista de la vida política y pública del surandino. Nació en Caraz, Ancash, el 16 de junio de 1878 y murió en Paucartambo, Cusco, en enero de 1951. Inicia su carrera de pintor en la Academia Concha de Lima, y luego de un significativo viaje por Ecuador, Panamá y Colombia regresa a Lima donde comienza su carrera fotográfica junto al destacado fotógrafo Fernando Garreaud, según los datos otorgados 
por la Fototeca Andina (Centro Bartolomé de las Casas, Cusco). Figueroa Aznar intentó ir más allá de la rutina rígida de la fotografía y de la pintura. En 1901 exhibió dos fotoóleos, uno de una mujer tocando el piano y otro de una joven semi-cubierta con tules vaporosos. Al siguiente año se trasladó a Arequipa, donde consiguió trabajo en el nuevo y lujoso estudio del fotógrafo Maximiliano T. Vargas. Allí pintó telones de fondo y carteles. Aprendió técnicas de iluminación y encontró en sus foto-óleos, una interesante manera de combinar la fotografía con la pintura (Poole, 2000: 207-42).

Hay quienes señalan que Figueroa era un pintor que hacía fotos. ¿Por qué afirmar que Figueroa Aznar le dio prioridad a la pintura frente a la fotografía? Valga la frase atribuida a Man Ray: "Pinto lo que no puede ser fotografiado, lo que viene de la imaginación o de sueños, fotografió lo que no deseo pintar, las cosas que tienen ya una existencia» (Sontag: 259).

En 1904 llega a Cusco, donde comienza a trabajar con el fotógrafo José Gabriel Gonzales. Según nos informó Luis Figueroa, hijo de Juan Manuel, Miguel Chani le traspasó su estudio en 1919 junto con 80 tarjetas de visita numeradas. Años más tarde abre su propio estudio que luego le traspasaría a Martín Chambi, en 1924. Por esta modalidad de la época de traspasarse los estudios, es que hoy hay grandes incongruencias y dudas respecto a la autoría de algunas fotografías.

Adelma Benavente señala que el encanto y la ancestral atracción de Cusco junto con la creciente reivindicación social del indio, fueron poderosos estimulantes para el desarrollo de la multifacética vocación artística de Figueroa, quien rápidamente se incorporó al círculo intelectual de la ciudad, convirtiéndose en uno de los artistas más influenciados por el indigenismo (1995: 9). Además, indica que la fotografía de Figueroa comprendía una multitud de temas, que estaban dominados por actores de obras indigenistas, autorretratos, indios y arquitectura inca, mostrando una refinada sensibilidad artística y una cautivante pasión por el movimiento. En relación al teatro que tanto sedujo a Figueroa, refiere César Itier:

El teatro quechua era probablemente el único espacio, en el Cuzco de la época, donde personas procedentes de distintos estratos de la sociedad podían comulgar en una misma experiencia cultural e intelectual y, por lo tanto, se constituyó una de las pocas oportunidades en que se hizo palpable la existencia de una comunidad nacional, por encima de las diferencias étnicas y culturales que separaban a los distintos grupos en la vida cotidiana (2000: 37).

Esta fotografía (lámina 8) que Juan Manuel Figueroa Aznar le tomara a Luis Ochoa, actor y dramaturgo, caracterizado como Ollanta, probablemente haya sido hecha para ilustrar la "Misión Peruana de Arte Incaico", compañía teatral cusqueña que partió de gira rumbo Buenos Aires. Pasando por La Paz en 1923, iba presidida por el historiador Luis E. Valcárcel (director artístico) y por el mismo Juan Manuel Figueroa Aznar (a cargo de la escenografía y decorados). Se presentaron fragmentos de las obras Ollanta y Manco II en quechua y números de danza y música con el objetivo de reconstruir y comunicar el pasado glorioso del imperio incaico. Permaneciendo en cartelera durante un mes en el teatro Colón de Buenos Aires, el mismo año en el que se presentara, por segunda vez, Richard Strauss dirigiendo sus óperas Salomé y Elektra (Plate, 2006: 40). Este contacto directo con una compañía de más de 47 actores y artistas peruanos, entre ellos Luis Ochoa y Julio Rouvirós, causó en los bonaerenses un impacto que caló en sus más íntimos sentimientos de identidad. Es indudable que el argentino de principio de si- 
glo se reencontró con sus hermanos andinos, según atestiguan los periódicos de la época. Elizabeth Kuon señala (2009: 213) que Juan Manuel Figueroa Aznar bocetó todos los decorados de las presentaciones teatrales además de registrar con su cámara la experiencia vivida en el viaje. Montó a la par una exposición con sus pinturas que reflejaban los paisajes andinos y escenas de la vida del indio en los Andes.

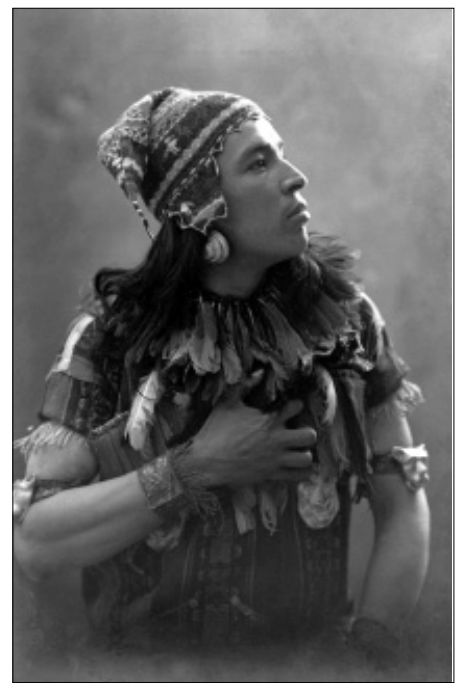

8. Luis Ochoa 1923, actor dramaturgo en el papel de Ollanta. Autor: Juan Manuel Figueroa Aznar.

El atuendo que lleva Luis Ochoa en la fotografía pretende representar la vestimenta inca. Sin embargo, muchos de los elementos que viste probablemente sean lo que en esa época se consideraba propio del vestuario del incario. El chullo (gorro de lana tejido), hoy sabemos que fue introducido por los españoles y adaptado por los andinos. Los brazaletes y las orejeras: creaciones de utilería. Las plumas que lleva en el pecho, a modo de cuello, no son apropiadas para un personaje serrano, en este caso se trataría más de una representación icónica de lo exótico que de fidelidad a la indumentaria inca. La actitud que refleja Luis Ochoa, su imponente perfil su mano tomándose el pecho, reflejan un sentimiento propio de la época que buscó engrandecer e idealizar lo inca.

\section{CUANDO PASE EL TEMBLOR}

La joven cordillera de Los Andes se encuentra emplazada en los labios de contacto de dos placas tectónicas (Nazca y Sudamericana). La potencia de la dinámica telúrica hace a la conceptualidad de lo andino; así, distintos procesos sísmicos han conformado hitos en la gesta cultural de los pueblos pertenecientes. Citaremos tres. En primera instancia aquel supuestamente sucedido a mediados del siglo XIV, durante el gobierno del Sapa Inca Cusi Yupanqui, quien ordenara la reconstrucción del Cusco y que diera lugar a las mayores obras arquitectónicas del incario. Tal es el tenor de su gestión que hasta hoy día se lo conoce como Pachacútec «el transformador del mundo» o como señalara Sarmiento 
«hijo del sol, señor, vuelta de la tierra» (Sarmiento, 2001: 93). ${ }^{30}$ Trescientos años después, el 31 de marzo de 1650, Cusco padeció otro violento terremoto. El mismo quedó registrado en el cuadro (frontispicio) que don Alonso Cortés de Monroy encargara pintar. En el lienzo se observa una vista de la Plaza de Armas y sus alrededores, viviendas destruidas incendios, explosiones y grupos humanos en distintos espacios abiertos de la ciudad. Es en la plaza mayor donde se representa el momento en el que el cabildo catedralicio decide sacar a la calle, en procesión, la imagen del Cristo negro. Sucediéndose, según el imaginario popular, el cese de los temblores, tras lo cual la ciudad se cubrió de una gran calma. Obsequio donado al Perú de Felipe II a fines del siglo XVI, se trata de un Crucificado de piel oscura y cabellera natural, hecho a semejanza del indio americano (Rodríguez, 2000: 94). Llega a América envuelta en un halo de misterio y virtud, ya en el viaje por el océano una gran tormenta con fuertes vientos huracanados; azotó la embarcación en que era trasladada, viéndose los tripulantes cerca de la muerte recurrieron a la imagen del Cristo negro y lo ataron al palo mayor del navío, implorándole amparo y protección. A los pocos minutos la tormenta cesó milagrosamente y todos estuvieron a salvo. Allí recibe su primer nombre: «Señor de las Tormentas» (Trevisan, 2001: 3) posteriormente, tras el cataclismo y hasta nuestros días se lo venera como «Señor de los Temblores»o «Taytacha Temblores».

El domingo 21 de mayo de 1950, a las 13:39 horas, se produjo en Cusco un terremoto con un índice de 7 puntos en la escala Mercalli. Murieron más de cien personas, quedando más de 30.000 sin albergue. Calculándose en 3000 las viviendas destruidas (Kubler, 1953: 5).

La UNESCO envía una misión al Cusco dirigida por George Kubler para diagnosticar los daños que se habían sucedido tras el sismo. El informe de la misma se publica en 1953 y consta de 59 fotografías, donde se documenta el estado de los edificios y monumentos afectados. Esta documentación no solo sirvió para evaluar los daños sino también para evitar demoliciones innecesarias, hechas tanto por propietarios ávidos de modernidad que pudieran optar cambiar el adobe por el cemento (Marín) como por quienes aspiraban a adjudicarse créditos nacionales e internacionales otorgados ante la catástrofe.

El informe de Kubler señala que uno de edificios incluidos en el ítem V (edificios intactos) es «El Triunfo», colindante con la actual catedral y que habría sido la primera iglesia donde se celebró misa en Cusco y según la tradición, el lugar en el que se apareció la Virgen a los españoles sitiados durante la rebelión de Manco Inca en 1536 (28). Llamativamente este templo albergaba desde hacía tres siglos la obra pintada por encargo de Monroy y que tras la catástrofe de 1950 se decidió trasladar a la Catedral, donde hasta la fecha de este escrito se conserva expuesta en la segunda capilla de la primera calle (lado del Evangelio).

Fotografías de las secuelas de terremotos en Perú ya existían, nos referimos a las tomadas durante aquel sucedido en 1868 y que tuviera por epicentro las cercanías de Arica (ciudad peruana en aquellos tiempos) y que afectase a distantes centros urbanos del Perú, principalmente a Arequipa. Citaremos aquí algunas, como la realizada por el oficial de la armada estadounidense L. B. Billings desde la fragata «Wateree», en la que se observan los daños provocados por el tsunami en el Morro de Arica, o la de los hermanos Courret (Eugene y Aquiles) donde se registran los destrozos provocados en

30 Según el diccionario de González Holguín «Pacha cuti pacha ticra: el fin del mundo, o grande destrucción pestilencia, ruyna, o pérdida o daño común». 
el Puerto de Arica. De las consecuencias edilicias del sismo en Arequipa existen varias imágenes atribuidas a Emilio Garreaud, a Félix Salazar y a Ricardo Villalba, algunas de ellas fueron excelentemente reproducidas, décadas después, por los hermanos Vargas (Carlos y Miguel), según nos lo transmitiera en forma personal su biógrafa Adelma Benavente. Destacamos de estas imágenes el «limitarse» a captar las consecuencias materiales del fenómeno natural. Los protagonistas son edificios, puertos, templos, plazas, accidentes orográficos, barcos. No encontramos al individuo afectado sino que nuevamente, como cuando nos referimos anteriormente a la publicación de Valcárcel y otros, su no presencia nos induce a deducirlo y en este caso particular a imaginar sus padecimientos y limitaciones.

En relación al sismo de 1950 relata Miguel H. Milla, periodista de Radio Cusco y corresponsal de La Crónica de Lima, en la nota publicada en el diario La República que le realizara Patricia Marín:

La ciudad estaba llena de velitas encendidas, la gente había ocupado la calle con sus carpas, no querían estar en sus casas. Por fin llegué a la radio para dar a conocer la lista de muertos y heridos. Eulogio Nishiyama, que trabajaba conmigo, me dijo: tengo las fotografías. Cuando comenzó todo, había cogido con un brazo a su hijo y con el otro la cámara, y salió a la carrera tomando fotos en el momento en que sucedía el terremoto, las vistas eran espectaculares, al día siguiente las mandamos en el avión (Marín, 2007: s/n).

Ricardo Castro Pinto, miembro de la Asociación Mutua del Señor de los Temblores, «observaba cómo el mercado de Santa Clara se movía como una jaula de ave; sobreponiéndose llegó a la Catedral. Eran las dos de la tarde. Habían sacado al Señor de los Temblores. La procesión estaba en la Plaza de Armas, pero no había quién tocara las campanas, Ricardo, tomó valor, subió a la torre y las tocó. La gente se arremolinó en el atrio».

Nacido en Cusco en 1920, hijo de padre japonés y madre cusqueña, Eulogio Nishiyama se dedica desde joven a la fotografía. Trabaja como corresponsal gráfico del diario La Crónica de Lima y como fotógrafo oficial de la Corporación Nacional de Turismo. Alterna su labor como reportero social para periódicos con viajes a zonas rurales y selváticas del Perú registrando la vida campesina, sus costumbres y tradiciones. Sus imágenes del terremoto de 1950 son publicadas en los más importantes diarios del mundo y siguen recorriendo muestras internacionales, no solo por su valor documental sino también por su calidad estética. Su hijo Carlos, destacado artista cusqueño dedicado también a la fotografía, nos habló del interés que su padre había adquirido por la fotografía antropológica a partir de los años 50. Destacándose también como cineasta, habiendo filmado documentales y largometrajes, entre los que sobresale Kukuli (1960), codirigida por Luis Figueroa y César Villanueva. Esta obra antológica marca el inicio de la cinematografía andina, siendo el primer filme hablado en quechua.

A diferencia de las tomas hechas en Arica y Arequipa las fotos de Nishiyama se centran en la gente y en este caso en particular, exclusivamente (lámina 9) mujeres, hombres, niños y adultos, indios, mestizos y blancos. Rezando con sus brazos extendidos y sus miradas dirigidas hacia la imagen del Señor de los Temblores que estaba en ese momento exhibido en la Plaza de Armas. Al igual que en el cuadro encargado por Monroy trescientos años atrás, la procesión acontecía ante el fenómeno extraordinario. 


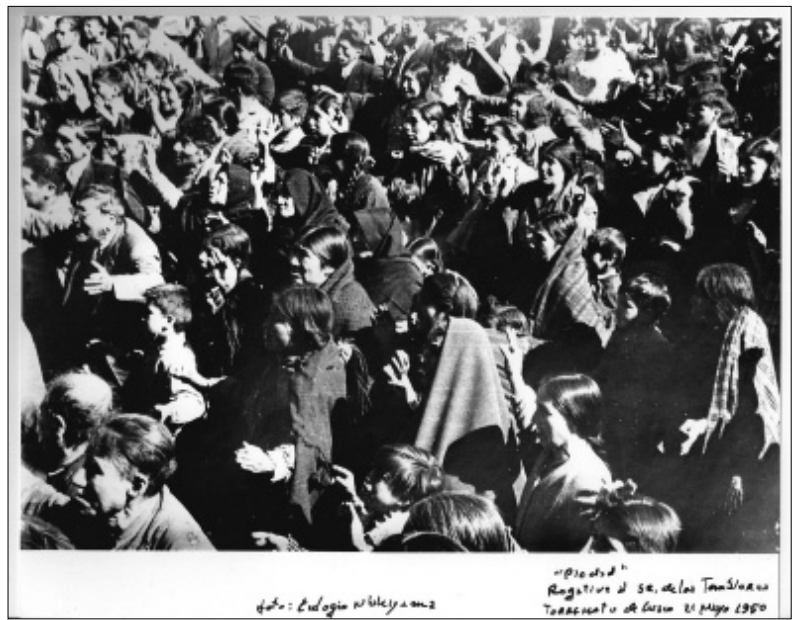

9. «Piedad» Rogativa al señor de los Temblores. Terremoto de Cusco 21 de mayo, 1950.

Autor: Eulogio Nishiyama.

Treinta fotografías formaron parte de una edición extraordinaria del diario La Crónica, producto de la temeridad de un joven corresponsal que entonces tenía 26 años de edad, tal cual lo escribe en la nota conmemorativa que el diario hiciera en 1986, la periodista Cynthia Pimentel, quien además transcribe las palabras que Nishiyama aduce eran la oración de los rogantes: «iApu Yaya, Jesucristo! ¡Qollanan María! Piedad Dios mío, perdona Dios mío y devuélveme ya tu amor!» (Pimentel, 1986: 6).

No solo documentó a su pueblo suplicando al Taytacha Temblores para que detuviese las réplicas y la devastación, también incluyó escenas donde compatriotas fallecieron o agonizaban bajo los escombros, damnificados durmiendo en carpas instaladas en espacios abiertos, secuencias de rescate y rostros de las víctimas con expresiones de desconcierto y desolación ante las pérdidas. Fotoperiodismo hecho por un profesional como lo revela con sus propias palabras en la misma nota: "Cumplí con mi tierra, con mi gente, y reaccioné como lo que soy, un reportero gráfico. No me acordé de nadie, ni siquiera de mi familia, hasta después» (Pimentel, 1986: 6). Seguramente el terremoto de Cusco de 1950 ha de haber finalizado e iniciado procesos de lo más variado en la vida de los cusqueños, algunos habrán quedado truncos otros habrán superado la coyuntura y otros habrán sido gestados esa misma tarde de mayo. Entre los primeros se encontraba el proyecto indigenista, a partir de esa fecha se disipó el movimiento como tal. Atravesándolo, traspasándolo: los fotógrafos y sus obras. Ellas siguen atravesándonos.

\section{CONCLUSIONES}

A lo largo de este artículo hemos citado una serie circunstancias referidas a la labor fotográfica en Los Andes peruanos donde el indio y su imagen resultan construidos desde diferentes ópticas y necesidades. Inicialmente hacemos referencia a los viajeros extranjeros, quienes elaboran un relato de lo andino para el lector europeo, prevaleciendo el valor de 
lo exótico; así como el espíritu aventurero y la capacidad de sobrellevar múltiples dificultades por parte de sus autores. Los fotógrafos, sus instrumentos y sus fotografías no aparecen mencionados en estos trabajos, pese a que sin ellos las ilustraciones que resultan esenciales en estas publicaciones hubiesen sido imposibles. Estos anónimos fotógrafos documentaron paisajes gente y costumbres in situ, que posteriormente artistas europeos transformaron en grabados de madera que no solo aparecieron en los textos mencionados sino que también fueron utilizados en revistas de la época como L'Illustration de París, The Illustrated London News, El Correo del Perú o Perú Ilustrado. Como señala Gesualdo (1990: 244) estas ilustraciones adquirían autenticidad bajo el rótulo en el epígrafe «d'apres une photographie» (tomada de una fotografía).

Mientras sucedían estos viajes, llegaban a Lima profesionales europeos dedicados a la fotografía social y los primeros fotógrafos peruanos comienzan a hacer escuela. Nace así la Escuela de Fotografía Cusqueña simultáneamente con el surgimiento del movimiento indigenista.

«Indígenas de Cusco» de Garreaud 1862 (lámina 2) y «Retrato de campesino» de Meza 1940 (lámina 3) revelan parte de este recorrido, de lo documental a lo ideal. La visión del extranjero de la segunda mitad del siglo XIX y la del peruano casi cien años después. Distintos marcos históricos y discursos visuales que responden a diferentes necesidades.

Observamos a través nuestro trabajo una meditada acción de fabricar, componer y construir lo indio utilizando la postura y vestimenta del fotografiado como principal recurso, durante la primera mitad del siglo XX en Cusco (láminas 2, 5, 7 y 8). La dificultad para mostrar o captar al indio no solo se hace manifiesta en la artificialidad y/o en la exageración de ciertos valores sino también en la ausencia representativa de los mismos (lámina 6).

Con el terremoto de 1950 se desmoronan también algunas idealizaciones, la intensidad del fenómeno natural en una tierra tan íntimamente ligada con su gente, pareciera haber despertado una imagen nueva que ya no necesitaría de tanto maquillaje para parecer andina.

El estar de las estrellas. Cuando contemplamos un cielo estrellado, la mayoría de las estrellas que vemos dejaron de existir hace millones de años. Es su luz la que sigue viajando a través del tiempo y del espacio dejándonos creer que su presencia es vida. No son lo que creemos ver y aún sabiéndolo nos resulta difícil no sentir que están vivas. Así la fotografía, exhumadora de recuerdos a la vez que gestora, nos presenta un pasado que será recuerdo aún sin quererlo. Iluminando la bóveda mnémica en fantástica ilusión.

Cusco, Perú - Martínez, Argentina / Invierno del $2009^{31}$

31 Agradecimientos especiales a: Renata Massa, Margarita Alvarado, Elizabeth Kuon Arce, Carlos Nishiyama, Luis Figueroa Yabar, Númitor Hidalgo, Jorge Flores Ochoa, Yvonne Stossel, Ivonne Casabonne, Roxana Abril, Lucero Massa, Carlos Ruiz Caro, Antonia Vega Centeno Bocangil, Andrea Espinar, Rafael Casabonne, Nilda Callañaupa, Esther Meza, Juan Mendoza, Pedro Mege Rosso, Antonia Miranda, Efraín Aranibal Álvarez, Luis Rosales, Mario Guevara, Adelma Benavente, Gerardo Mora Rivera, Fototeca Andina CBC, Martha Mantilla, Instituto Americano de Arte (Cusco), Museo Inka y uno especial al inventor del programa Skype. 


\section{REFERENCIAS}

Alvarado, Margarita. (2000). Indian Fashion. La imagen dislocada del «indio chileno». Estudios Atacameños 20: 137-151.

Benavente, Adelma. (1992). La escuela cusqueña de fotografia. Revista del Instituto Americano de Arte 13: 139-140.

-. (1995). Photography in Southern Peru, 1900-1930. Peruvian Photography: Images fromthe Southern Andes 1900-1945 (pp. 8-12). Colchester University of Essex.

Buck, Daniel. (1994-1995). Pioneer Photography in Bolivia: Register of Daguerreotypists and Photographers, 1840s-1930s. Bolivian Studies (p. 122). United States of America.

Chervin, Arthur. (1908). Anthropologie Bolivienne. Vol.1: Ethnologie, Demographie, Photographie Metrique. París.

Flores Ochoa, Jorge. (1990). Incanismo, resistencia y continuidad cuzqueños. El Cuzco: Resistencia y continuidad (pp. 9-15). Cusco: Ed. Andina.

Flores Ochoa, Jorge A., Elizabeth Kuon Arce y otros. (2007). Cuzco, del mito a la historia. Lima: Banco de Crédito.

Fuentes Delgado, Manuel Atanasio. (1867). Lima. Apuntes históricos, descriptivos, estadísticos y de costumbres. París: Librería de Firmin Didot, hermanos, hijos y C.

Gesualdo, Vicente. (1990). Historia de la Fotografía en América. Desde Alaska hasta Tierra del Fuego en el siglo XX. Buenos Aires: Editorial Sui Generis.

Giraudo, Silvia y Patricia Arenas. (2004). Científicos europeos en el altiplano bolivianoargentino: antropología, expediciones y fotos. Anales de Museo de América 12: 125 146.

Gómez, Juan Guillermo. (1994). Stübel y Reiss: dos viajeros alemanes en la Colombia del siglo XIX, Cartas de Alpbons Stübel: Colombia. Boletín Cultural y Bibliográfico 35 (Volumen XXXI). Bogotá. Obtenido desde <http://www.lablaa.org/blaavirtual/ publicacionesbanrep/boletin/boleti1/bol35/indice.htm>.

González Holguín, Diego. (1989) . Vocabulario de la Lengua general de todo el Perú llamada Lengua Qquichua o del Inca (1608). Lima: Universidad Nacional Mayor de San Marcos.

Gutiérrez, José Carlos. (2007). La generación cuzqueña de 1927. Lima: Ed. Horizonte.

Heredia, Jorge. (1993). Avatares de la obra del fotógrafo peruano Martin Chambi (18911973) y reseña de dos monografías recientes. Hueso humero 29: 145-177. Lima: Ed. Mosca azul.

Huayhuaca, José Carlos. (1992). Cien Años de Martin Chambi. Revista del Instituto Americano de Arte 13:137-8. Cusco.

Itier, César. (2000). El teatro quechua en el Cusco. Indigenismo Lengua y Literatura en el Perú moderno. Tomo II. Ed. IFEA y CBC: Cusco.

Krauskopf, Gunther. (2002). Tres viajeros europeos pre cientificos en Bolivia del siglo XIX: Falb, Wiener, Ver. La Paz: Instituto de arqueología boliviana de la Universidad San Francisco de Asís.

Kohl, Frank Stephan. (2005). Um olhar europeu em 2000 imagens: Alphons Stübel e sua coleção de fotografias da América do Sul. Revista STUDIUM 21, inverno. Obtenido en mayo desde <http://www.studium.iar.unicamp.br/21/04.html>. 
Kubler, George. (1953). Cuzco. Reconstrucción de la ciudad y restauración de sus monumentos. Informe de la misión enviada por la UNESCO en 1951 por George Kubler. París: Museos y Monumentos III. UNESCO.

Kuon Arce, Elizabeth. (1981). Incanismo y Arte en el Cusco de los años 20. Revista Crónicas Urbanas 1: 118-124. Cusco.

Kuon Arce, Elizabeth, Rodrigo Gutiérrez Viñuales, Ramón Gutiérrez y Graciela Viñuales. (2009). Cuzco-Buenos Aires, Ruta de la intelectualidad americana (1900-1950). Lima: Universidad Nacional San Martín de Porres.

Massa, Luis y Luis Rosales. (2009). Científicos ilustrados e ilustradores de la mayística. Coloquio Binacional Argentino-Peruano, Perspectiva Latinoamericana. ANTI, número especial (pp. 335-364). Buenos Aires: Instituto Superior del profesorado Joaquín González-Centro de Investigaciones Precolombinas.

Majluf, Natalia, Luis Eduardo Wuffarden. (2001). El primer siglo de la fotografía. Perú 1842-1942. La recuperación de la memoria, Perú 1842-1942 (pp. 20-133). Lima: Museo de Arte de Lima y Fundación Telefónica.

Marín, Patricia. (2007). Cusco imperial en escombros. Diario La República, Perú, 25 junio, obtenido desde <http://www.larepublica.pe/archive/all/domingo/20070625/1/ node/43342/todos/1558>.

Mege Rosso, Pedro. (2009). Viviendo en un mundo material. En imprenta.

McElroy, Keith. (1986). Ephraïm George Squier: photography and the illustration of peruvian antiquities. History of photography 10 (2):99-129.

Pimentel, Cynthia. (1986). Yo estuve en el terremoto del Cusco. Diario La Crónica. Lima. Edición del día martes 15 de abril.

Plate, Leonor. (2006). Óperas Teatro Colón. Esperando el centenario. Tomo I. Buenos Aires: Editorial Dunken.

Poole, Deborah. (1991). Fotografía, fantasía y modernidad. Márgenes (pp 109-141). Lima: Sur Casa de estudios del Socialismo.

-. (2000). Visión, raza y modernidad. Trad. Martínez Maruja. Lima: Sur Casa de Estudios del Socialismo.

Ranney, Edward. (2001). Martin Chambi, de Coasa y del Cusco. La recuperación de la memoria, Perú 1842-1942 (pp. 134-55). Lima: Museo de Arte de Lima y Fundación Telefónica.

Riviale, Pascual. (2003). Charles Wiener o el disfraz de una misión lúcida. Viajeros por el Nuevo Mundo y su aporte a la ciencia (siglos XVIII y XIX). Bulletin de I'Institut Français d' Études Andines 3: 545-546, tomo 32.

Rodríguez, Hernán. (2001). Historia de la Fotografía. Fotógrafos en Chile durante el siglo XIX. Santiago: Centro Nacional del Patrimonio Fotográfico.

Rodríguez G. de Ceballos, Alfonso. (2000). Usos y funciones de la imagen religiosa en los virreinatos americanos. Los Siglos de Oro en los Virreinatos de América 15501700. Madrid: Sociedad Estatal para la conmemoración de los centenarios de Felipe II y Carlos V.

Sarmiento de Gamboa. (2001). Historia de los inkas. (c1572). Madrid: Miraquano Ediciones.

Schaedel, Richard P. (1988). La etnografía Muchik en las fotografías de H. Brüning 1886-1925. Lima: Ed. COFIDE. 
Schwarz, Herman. (2007). Fotógrafos franceses en el Perú del siglo XIX. Bulletin de I'Institut Français d' Études Andines 1, tomo 36 (pp. 39-49). IFEA. Lima.

Sontag, Susan. (2008). Sobre la fotografia. Trad. Carlos Gardini. México: Ed. Alfaguara.

Trevisan Paula. (2001). Taytacha Temblores Periódico. Cusco Weekly 25: 3. Marzo.

Trevisan, Paula, Patricia Malaga y Luis Massa. (2002). Textiles cusqueños: patrimonio vivo. Revista Rumbos 34. Año VI. Lima.

Vivas Sabroso, Fernando. (1992). Señores del Lente. Revista Caretas 1218: 61.6 de Julio.

Recepción: septiembre de 2009

Aceptación: octubre de 2009 